\title{
PENGARUH KESADARAN MERK, PERSEPSI KUALITAS, DAN LOYALITAS MERK TERHADAP KEPUTUSAN PEMBELIAN HANDPHONE VIVO PADA ANGKASA CELL DI KABUPATEN BLORA
}

\author{
Diva Riza Fahlefi, Ariyani Indriastuti
}

Program Studi Manajemen STIE SEMARANG

\begin{abstract}
The increasing level of competition for companies has resulted in companies competing to win consumers. The purpose of this study was to analyze the effect of brand awareness, perceived quality and brand loyalty on Mobile Vivo Purchase Decisions in Angkasa Cell Store in Blora Regency. The population in this study is all customers or consumers who used or made mobile phone purchasing decisions in Angkasa Cell Store in Blora Regency which amounts to 154 customers. The sampling technique used was purposive sampling to obtain 63 respondents. The method of data analysis uses multiple linear regression. The results of the study show that the brand awareness variable obtains a tcount of 3.958> ttable 1.66) with a significance of 0,000 means brand awareness has a positive and significant influence on purchasing decisions. The perceived quality variable with a tcount (3.694)> t table (1.66) with a significance of 0,000 means that the perception of quality has a positive and significant influence on purchasing decisions. Brand loyalty variable with a value of tcount $(3,438)>t$ table (1.66) with a significance of 0.001, means that brand loyalty has a positive and significant influence on purchasing decisions. In order for the consumer confidence of Vivo mobile phone in Angkasa Cell Store in Kabupaten Blora can be stronger and increase purchasing power, it is recommended to increase brand awareness through promotion.
\end{abstract}

Keywords: Brand Awareness, Perception of Brand Loyalty Quality and Purchasing Decision.

\begin{abstract}
ABSTRAK
Tingkat persaingan yang semakin tinggi bagi perusahaan mengakibatkan perusahaan saling bersaing untuk merebut konsumen. Tujuan penelitian ini adalah, menganalisispengaruhkesadaran merk, persepsi kualitas dan loyalitas merk terhadap Keputusan PembelianHandphone Vivo pada Angkasa Cell di Kabupaten Blora.Populasi dalam penelitian ini adalah seluruh konsumenAngkasa Celldi Kabupaten Bloraberjumlah 154. Teknik pengambilan sampel yang digunakan adalah purposive samplingsehingga diperoleh 63 responden. Metode analisis data menggunakan regresi linier berganda.Hasil penelitian menunjukan bahwa variabel kesadaran merkmemperoleh nilai $t_{\left.\text {hitung } 3,958>t_{\text {tabel }} 1,66\right)}$ dengan signifikansi0,000berarti kesadaran merkmemiliki pengaruh positif dan signifikan terhadapkeputusan pembelian. Variabel persepsi kualitas dengan nilai $t_{\text {hitung }}$ $(3,694)>t_{\text {tabel }}(1,66)$ dengan signfikansi0,000berarti persepsi kualitas memiliki pengaruh positif dan signifikan terhadapkeputusan pembelian. Variabelloyalitas merkdengan nilai thitung $(3,438)>$ $\mathrm{t}_{\text {tabel }}(1,66)$ dengan signifikansi 0,001 , berarti loyalitas merk memiliki pengaruh positif dan signifikan terhadapkeputusan pembelian.Agar kepercayaan konsumen pada handphone Vivo pada Angkasa Cell di Kabupaten Blora semakin kuat dan keputusan pembelian semakin meningkat maka disarankan untuk meningkatkan kesadaran merk melalui promosi.
\end{abstract}

Kata kunci: KesadaranMerk, Persepsi Kualitas Loyalitas MerkDan Keputusan Pembelian. 


\section{PENDAHULUAN}

Perkembangan dunia bisnis saat ini menunjukkan kemajuan yang sangat pesat, dengan tujuan untuk mendorong kemajuan ilmu pengetahuan dan tekhnologi. Hal ini dapat dilihat dengan banyaknya perusahaan yang bermunculan serta bersaingnya antar produk dan pelayanan. Semakin meningkatnya persaingan antar produk sejenis, maka perusahaan saling bersaing merebutkan konsumen.

Telepon selular merupakan perkembangan dari telepon rumah yang dapat dibawa kemana saja, karena handphone bersifat mobile dan juga dapat membantu kegiatan manusia bukan hanya untuk menelpon namun dapat mengirim sms / pesan, internet, mendengarkan musik, bahkan mengabadikan kegiatan manusia dengan teknologi kamera. Semakin lama pola pikir konsumen akan selalu berubah sesuai dengan perkembangan jaman. Konsumen saat ini sangatlah kritis dalam memilih suatu produk, sampai pada keputusan untuk membeli produk tersebut.

Produk handphone semakin berkembang dan memanjakan konsumen dengan berbagai kelebihan yang dimiliki. Pada saat ini muncul banyak merk dipasar yang menawarkan berbagai fitur atau perbedaan produk dengan harga yang lebih murah dibanding merk lain di pasar. Hal ini membuat konsumen mempunyai banyak pilihan dalam mengambil keputusan membeli. Kualitas handphone berpengaruh besar dalam pengambilan keputusan membeli. Dengan harga yang lebih terjangkau dengan merk yang banyak memberikan kualitas handphone dengan fitur terbaru. Handphone Vivo adalah salah satu merk handphone yang berasal dari negara China yang sudah masuk ke Indonesia yang namanya mulai dikenal masyarakat Indonesia karena memiliki fitur kamera yang bagus dan design yang up to date.

Ketika melakukan pembelian maka konsumen akan mempertimbangkan beberapa hal dalam fikirannya. Dan seseorang yang akan sadar atas merk tersebut dengan siap untuk segera melakukan tindakan. Demikian juga dengan asosiasi merk yang ada terhadap sebuah produk atau merk yang sama dalam benak setiap konsumen berbeda-beda. Presepsi kualitas merupakan proses yang menyangkut masuknya pesan atau informasi kedalam otak manusia, melalui persepsi manusia terus menerus mengadakan hubungan dengan lingkungannya. Selain presepsi kualitas loyalitas merk juga merupakan perubahan perilaku seseorang yang timbul dari pengalaman masa lalunya. Konsumen memperoleh berbagai pengalamannya dalam pembelian produk, mengkonsumsi produk, dan merk produk apa yang disukainya. Loyalitas merk merupakan aspek terprogram yang dilakukan oleh manusia untuk mendapatkan informasi atau pengetahuan yang akan digunakan dalam memperloeh suatu hal yang diinginkan. 
Demikian juga loyalitas merk yang sudah melekat merupakan hal yang tidak kalah pentingnya. Loyalitas merk adalah evaluasi, perasaan emosi, dan kecenderungan tindakan yang menguntungkan atau tidak menguntungkan dan bertahan lama pada seseorang terhadap suatu objek atau gagasan tertentu.

\section{KAJIAN TEORITIS}

1. Pengertian Keputusan Pembelian

Menurut Hawkins. (2007), keputusan pembelian adalah sebagai suatu kegiatan membeli kembali yang dilakukan oleh konsumen terhadap suatu produk dengan merek yang sama tanpa diikuti oleh perasaan yang berarti terhadap produk tersebut. Terdapat dua kemungkinan yang dapat menyebabkan seseorang melakukan pembelian ulang suatu produk. Pertama, konsumen merasa puas dengan pembelian yang mereka lakukan. Kedua, pelanggan merasa tidak puas, tetapi mereka tetap melakukan pembelian ulang. Untuk kemungkinan kedua ini biasanya disebabkan mereka menganggap biaya yang harus mereka keluarkan untuk mencari, mengevaluasi, dan mengadopsi produk dengan merek lain (switching cost) terlalu tinggi.

Sedangkan menurut Cronin dan Morris (1989), keputusan pembelian adalah sesuatu pada komitmen terhadap produk atau jasa yang timbul setelah menggunakan mereka, sehingga timbul gagasan untuk konsumsi lagi.

Menurut Peter dan Olson (2000), keputusan pembelian ulang adalah ketika konsumen melakukan pembelian ulang karena adanya suatu dorongan dan perilaku membeli secara berulang yang dapat menumbuhkan suatu loyalitas terhadap apa yang dirasakan sesuai untuk dirinya.

\section{Pengertian Merek}

Menurut Aaker (1997) merek adalah nama dan atau simbol yang bersifat membedakan (seperti sebuah logo, cap, atau kemasan) dengan maksud mengidentifikasi barang atau jasa dari seorang penjual atau sebuah produk tertentu, dengan demikian membedakannya dari barang-barang dan jasa yang dihasilkan pesaing. Jadi merek mengidentifikasi penjual atau pembuat merek dapat berupa nama, merek dagang, logo, atau simbol lain.

Sedangkan menurut Kotler (2001), merek adalah nama, istilah, tanda atau rancangan, atau kombinasi dari semua ini yang dimaksudkan untuk mengidentifikasikan produk atau jasa dari satu atau kelompok atau membedakannya dari produk pesaing. 
Menurut Kartajaya (2004) merek adalah kelengkapan produk, jadi setiap produk harus memiliki merek, sehingga konsumen tidak mengalami kesulitan dalam mencari produk kembali produk tersebut. Merek juga mempunyai fungsi untuk membedakan kualitas produk yang satu dengan yang lainnya. Selain itu merek juga merupakan suatu jaminan dari produsen atas kualitas dari produk yang dihasilkan.

\section{Kesadaran Merek (Brand Awareness)}

Menurut Aaker (1996), kesadaran merek adalah kesanggupan seorang calon pembeli untuk mengenali atau mengingat kembali bahwa suatu merek merupakan bagian dari kategori produk tertentu.

Sedangkan menurut Durianto. (2004). Brand awareness atau kesadaran merek menggambarkan kesanggupan seorang calon pembeli untuk mengenali, mengingat kembali suatu brand sebagai bagian dari suatu kategori produk tertentu. Pada umumnya konsumen cenderung membeli produk dengan brand yang sudah dikenalnya atas dasar pertimbangan kenyamanan, keamanan dan lain-lain. Bagaimanapun juga brand yang sudah dikenal menghindarkan konsumen dari risiko pemakaian dengan asumsi bahwa brand yang sudah dikenal dapat diandalkan.

\section{Persepsi Kualitas (Perception Quality)}

Menurut Schiffman dan Kanuk (2008) persepsi kualitas adalah penilaian konsumen terhadap kualitas barang atau jasa yang berdasarkan informasi yang diterima berdasarkan asosiasi terhadap produk tersebut. Sedangkan menurut Aaker (1991) persepsi kualitas adalah sebagai persepsi pelanggan terhadap keseluruhan kualitas atau keunggulan suatu produk atau jasa layanan berkaitan dengan apa yang diharapkan oleh pelanggan.

Menurut Aaker (1997) menjelaskan persepsi kualitas yaitu konsumen terhadap keseluruhan kualitas atau keunggulan suatu produk atau jasa berkaitan dengan yang diharapkan oleh konsumen. Selanjutnya Aaker menegaskan satu hal yaitu bahwa persepsi kualitas merupakan persepsi para konsumen, oleh sebab itu persepsi kualitas tidak dapat diterapkan secara obyektif. Selain itu persepsi kualitas, konsumen akan melibatkan apa yang penting untuk konsumen karena setiap konsumen memiliki kepentingan yang berbeda-beda terhadap suatu produk atau jasa.

\section{Loyalitas Merk (Brand Loyalty)}

Menurut Schiffman dan Kanuk (2009), loyalitas merek adalah preferensi konsumen secara konsisten untuk melakukan pembelian pada merek yang sama pada produk yang 
spesifik atau kategori pelayanan tertentu. Loyalitas merek adalah sebuah komitmen yang kuat dalam berlangganan atau membeli suatu merek secara konsisten di masa yang akan datang.

Menurut Mowen \& Minor (2002), (brand loyalty) dipandang sebagai sejauh mana seorang pelanggan menunjukan sikap positif terhadap suatu merek, mempunyai komitmen pada merek tertentu, dan berniat untuk terus membelinya dimasa depan. Menurut Aarker dalam Nagar (2009) berpendapat bahwa loyalitas merek menujukan pola pembelian yang konsisten terhadap merek tertentu sepanjang waktu dan juga sikap menyenangkan terhadap sebuah merek. Loyalitas merek berkembang ketika merek sesuai dengan personalitas atau image diri konsumen atau ketika merek menawarkan kepuasan dan keuntungan unik yang dicari konsumen.

Sedangkan menurut Giddens (2002) menyebutkan loyalitas merek adalah pilihan yang dilakukan konsumen untuk membeli merek tertent dibandingkan merek yang lain dalam satu kategori produk. Hal ini terjadi karenakonsumen merasa bahwa merek menawarkan fitur produk yang tepat, gambar atau tingkat kualitas diharga yang tepat. Sedangkan menurut Sutisna (2001) loyalitas merek (brand loyalty) bisa didefinisikan sebagai sikap menyenangi suatu merek yang diwujudkan dalam pembelian yang konsisten terhadap merek itu sepanjang waktu.

Gambar 2.1

Kerangka pemikiran

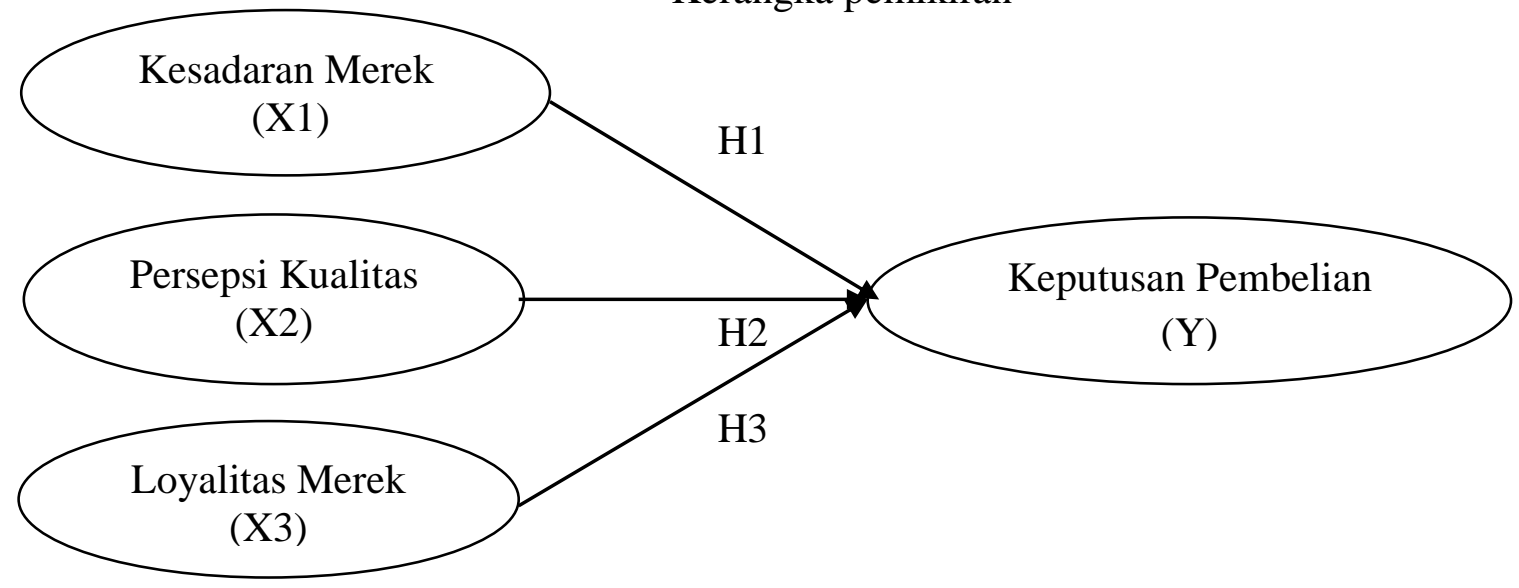

\section{METODOLOGI}

Populasi dalam penelitian ini adalah seluruh pelanggan atau konsumen, yang menggunakan atau melakukan keputusan pembelian handphone padaangkasa celldi Kabupaten Blora, berjumlah 154 pelanggan. Teknik pengambilan sampel menggunakan purposive samping yaitu konsumen Angkasa Celldi Kabupaten Blora, yang telah melakukan transaksi pembelian. Karakteristik ini diambil dengan alasan bahwa konsumen yang telah melakukan transaksi 
pembelian cenderung merupakan konsumen yang melakukan keputusan pembelian jadi sampel dalam penelitian ini adalah Handphone Merek Vivo berjumlah 63

Variabel bebas (independen) adalah model yangdiukur dalam penelitian ini yaitu:

1. Kesadaran Merek $\left(\mathrm{X}_{1}\right)$ Brand awareness atau kesadaran merek menggambarkan kesanggupan seorang calon pembeli untuk mengenali, mengingat kembali suatu brand sebagai bagian dari suatu kategori produk tertentu.

2. Persepsi Kualitas $\left(\mathrm{X}_{2}\right)$, Persepsi kualitas merupakan persepsi para konsumen, oleh sebab itu persepsikualitas tidak dapat diterapkan secara obyektif

3. Loyalitas Merek $\left(\mathrm{X}_{3}\right)$, Loyalitas merek adalah preferensi konsumen secara konsisten untuk melakukan pembelian pada merek yang sama pada produk.

Variabel terikat dalam penelitian ini adalah Keputusan pembelian. Keputusan pembelian adalah sebagai suatu kegiatan membeli kembali yang dilakukan oleh konsumen terhadap suatu produk dengan merek yang sama tanpa diikuti oleh perasaan yang berarti terhadap produk tersebut.

Metode analisa data dalam penelitian ini adalah: Uji Asumsi Klasik. Tujuan pengujian asumsi klasik ini adalah untuk menguji dan mengetahui kelayakan atas model regresi yangdigunakan dalam penelelitian ini, pengujian meliputi: Uji Normalitas, Uji Multikolinieritas, Uji Heteroskedastisitas.Uji Signifikansi Parameter Individual (Uji Statistik t), Uji kesesuaian model (Uji F), Koefisien Determinasi (R2), Analisis regresi linier berganda

$$
\begin{aligned}
\mathrm{Y}= & \beta_{0}+\beta_{1} \text { Kesadaran Merek }+\beta_{2} \text { Persepsi Kualitas }+\beta_{3} \text { Loyalitas Merek }+\varepsilon \\
& \mathrm{X} 1=\text { Kesadaran Merek } \\
& \mathrm{X} 2=\text { Persepsi Kualitas } \\
& \mathrm{X} 3=\text { Loyalitas Merek } \\
& \mathcal{E}=\text { kesalahan residual (eror) }
\end{aligned}
$$

\section{Hasil Penelitian}

Berikut ini akan dijelaskan mengenai karakteristik responden berdasarkan, jenis kelamin,danpenghasilan. Tabel berikut adalah tabulasi responden berdasarkan jenis kelamin.

Tabel 1

Responden Berdasarkan Jenis Kelamin

\begin{tabular}{lcc}
\hline \multicolumn{1}{c}{ Jenis Kelamin } & Jumlah & Prosentase $(\%)$ \\
\hline Perempuan & 38 & $70 \%$ \\
Laki-Laki & 25 & $30 \%$ \\
Jumlah & 63 & $100 \%$ \\
\hline
\end{tabular}

Sumber: Data primer yang diolah 2019 
Berdasarkan pada tabel diatas dapat diketahui bahwa sebagian besarresponden pada penelitian ini adalah responden perempuan yaitu 38 orang atau $70 \%$ dan reponden laki-laki sebanyak 25 orang atau $30 \%$.

Tabel 2

Responden Berdasarkan Penghasilan

\begin{tabular}{lcc}
\hline \multicolumn{1}{c}{ Penghasilan /(Bulan) } & Jumlah & Prosentase $(\%)$ \\
\hline$<2$ juta & 27 & $56 \%$ \\
$3-4$ juta & 16 & $17 \%$ \\
$>4$ juta & 20 & $27 \%$ \\
Jumlah & 63 & $100 \%$ \\
\hline
\end{tabular}

Sumber: Data primer yang diolah 2019

Berdasarkan pada tabel diatas dapat diketahui bahwa sebagian besarresponden pada penelitian ini adalah responden berpenghasilan kurang dari 2 juta per bulan sebanyak 27 orang 56 $\%$ dan sebanyak 16 orang yang berpenghasilan 3-4 juta per bulan sebanyak $17 \%$ dan 20 orang berpengahasilan lebih dari 4 juta per bulan sebanyak $27 \%$

\section{Pengujian Asumsi Klasik}

Analisis uji asumsi klasik untuk menguji kelayakan data yang digunakan dalam penelitian (Imam Ghozali, 2005 : 19)

a. Uji Normalitas

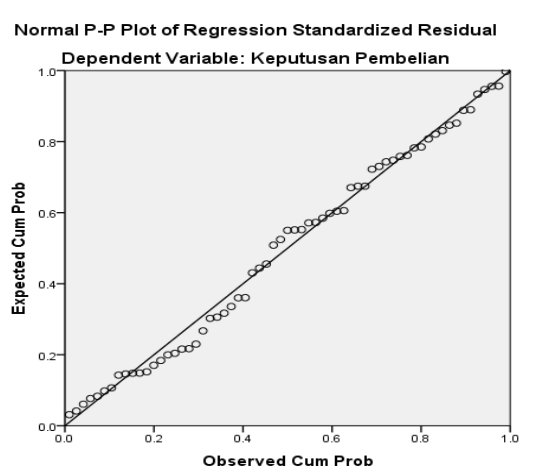

Dari gambar diatas menunjukkan bahwa plotting data tidak jauh dari garis diagonalnya dan menempel pada garis diagonal.Hal ini berarti bahwa data terdistribusi normal.

\section{b. Uji Multikoleniaritas}

Uji multikolonieritas bertujuan untuk menguji apakah dalam model regresi ditemukan adanya korelasi antar variabel bebas. 
Tabel 3

Uji Multikoleniaritas

\begin{tabular}{|c|c|c|c|}
\hline \multicolumn{4}{|c|}{ Coefficients $^{a}$} \\
\hline \multirow[t]{2}{*}{ Model } & & \multicolumn{2}{|c|}{ Collinearity Statistics } \\
\hline & & Tolerance & VIF \\
\hline \multirow{4}{*}{1} & (Constant) & & \\
\hline & Kesadaran Merk & .707 & 1.414 \\
\hline & Persepsi Kualitas & .698 & 1.432 \\
\hline & Loyalitas Merk & .693 & 1.444 \\
\hline
\end{tabular}

Dari tabel tersebut terlihat setiap variabel bebas mempunyai nilai tolerance $\geq 0,1$ dan nilai VIF $\leq 10$. Jadi dapat disimpulkan bahwa tidak ada multikolinieritas antar variabel bebas dalam model regresi ini.

c. Uji Heteroskedastisitas

Uji Heteroskedastitas bertujuan menguji apakah dalam regresi terjadi ketidaksamaan variance dari residual suatu pengamatan ke pengamatan yang lain.

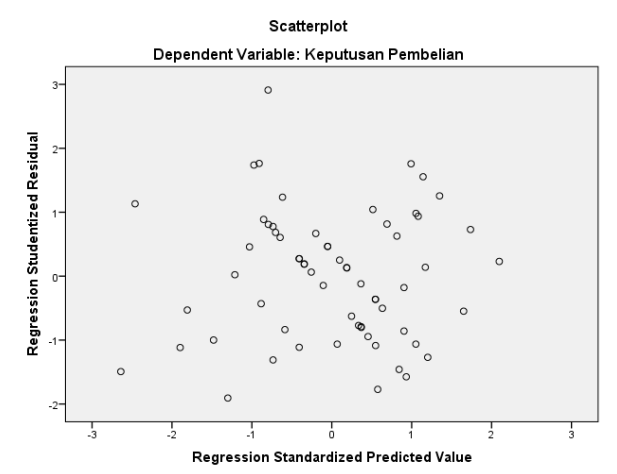

Pada gambar di atas menunjukan hasildai uji heteroskedastisitas adalah dengan mengamatipenyebaran yang acak menunjuk kan model regresi yang abik, dengan kata lain tidak terjadi heterokedastisitas.

2. Analisis regresi Linier Berganda

Analisis regresi linier berganda pada dasarnya adalah studi mengenai ketergantungan variabel dependen (terikat) dengan satu atau lebih variabel independen, hasil dari uji regresi linier berganda adlah sebagai berikut:

Tabel 4

Regresi Linier Berganda

\begin{tabular}{|c|c|c|c|}
\hline \multicolumn{4}{|c|}{ Coefficientsa } \\
\hline \multirow[t]{2}{*}{ Model } & & \multicolumn{2}{|c|}{ Unstandardized Coefficients } \\
\hline & & B & Std. Error \\
\hline \multirow{4}{*}{1} & (Constant) & .824 & 1.408 \\
\hline & Kesadaran Merk & .301 & .076 \\
\hline & Persepsi Kualitas & .303 & .082 \\
\hline & Loyalitas Merk & .242 & .070 \\
\hline \multicolumn{4}{|c|}{ a. Dependent Variable: Keputusan Pembelian } \\
\hline
\end{tabular}


Dari hasil analisis dapat diketahui persamaan regresi dari penelitian ini. Adapaun persamaan regresi linier yang terbentuk adalah:

$$
Y=0,824+0,301 X_{1}+0,303 X_{2}+0,0,242 X_{3} .
$$

\section{Uji Koefisien Determinasi}

Uji ini digunakan untuk mengetahui seberapa variasi variabel bebas terhadap variabel terikat. Namun kelemahan mendasar penggunaan koefisien determinasi $\left(\mathrm{R}^{2}\right)$ adalah bias terhadap jumlah variabel independen (bebas) yang dimasukkan ke dalam model. Hasil dari koefisien determinasi sebagai berikut:

Tabel 5

Koefisien Determinasi

\begin{tabular}{|c|c|c|c|c|}
\hline & \multicolumn{4}{|c|}{ Model Summary ${ }^{b}$} \\
\hline Model & $\mathrm{R}$ & R Square & $\begin{array}{l}\text { Adjusted R } \\
\text { Square }\end{array}$ & $\begin{array}{c}\text { Std. Error of the } \\
\text { Estimate }\end{array}$ \\
\hline 1 & $.811^{a}$ & .658 & .641 & 1.49772 \\
\hline
\end{tabular}

a. Predictors: (Constant), Loyalitas Merk, Kesadaran Merk, Persepsi Kualitas

b. Dependent Variable: Keputusan Pembelian

Berdasarkan tabel diatas menunjukkan nilai angka koefisien determinasi ( $R$ Square) sebesar 0,658 Hal ini berarti bahwa variabel Kesadaran merek, Persepsi Kualitas Loyalitas merek terhadap Keputusan Pembelian,mempunyai peranan 65,8\% dapat menjelaskan atau menerangkan variabel Keputusan Pembelian, sedangkan sisanya sebesar 44,2\% dijelaskan oleh variabel lain yang tidak ada dalam model.

\section{a. Uji Kesesuaian Model}

Uji Kesesuaian model dimaksudkan untuk mengetahui apaakah model yang disusun merupakan model yang fit. Berdasarkan hasil pengujian didapatkan nilai $\mathrm{F}_{\text {hitung }}=$ 37,905sedangkan nilai $F_{\text {tabel }}=2.49$. $F_{\text {hitung }} 37,905>F_{\text {tabel }}$ 2.49dengan signifikansi 0,00sehingga dapat disimpulkan bahwa model adalah sesuai/fit.

Tabel 6

Uji Kelayakan Model

ANOVA $^{\mathrm{a}}$

\begin{tabular}{|c|c|c|c|c|c|c|}
\hline \multicolumn{2}{|c|}{ Model } & Sum of Squares & $\mathrm{df}$ & Mean Square & $\mathrm{F}$ & Sig. \\
\hline \multirow{3}{*}{1} & Regression & 255.082 & 3 & 85.027 & 37.905 & $.000^{b}$ \\
\hline & Residual & 132.346 & 59 & 2.243 & & \\
\hline & Total & 387.429 & 62 & & & \\
\hline
\end{tabular}

a. Dependent Variable: Keputusan Pembelian

b. Predictors: (Constant), Loyalitas Merk, Kesadaran Merk, Persepsi Kualitas 


\section{b. Uji Hipotesis ( $\mathrm{t}$ test)}

Uji t digunakan untuk mengetahui sejauh mana variabel bebas berpengaruh terhadap variabel terikat, dengan tingkat kesalahan $5 \%$.

\begin{tabular}{llcr}
\multicolumn{5}{c}{ Hasil Uji Hipotesis Parsial Dengan t-test } \\
Coefficients & & \\
\hline Model & & t & Sig. \\
& & & \\
\hline & & .585 & .560 \\
1 & (Constant) & 3.958 & .000 \\
& Kesadaran Merk & 3.694 & .000 \\
& Persepsi Kualitas & 3.438 & .001 \\
\hline & Loyalitas Merk & a. Dependent Variable: Keputusan Pembelian &
\end{tabular}

a. Pengujian hipotesis 1

VariabelKesadaran merek terhadap Keputusan pembelian handphone Vivo.Berdasarkan tabel Hasil Uji t untuk Variabel Kesadaran merek, diperoleh nilai thitung $=3,958$ sedangkan $t_{\text {tabel }}$

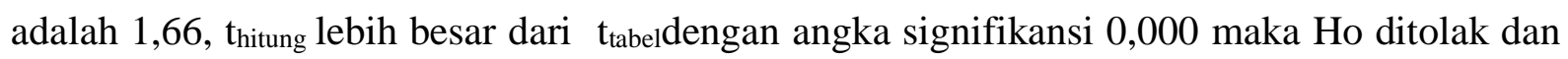
Ha diterima. Hal ini menunjukan bahwa variabel Kesadaran merek mempunyai pengaruh positif signifikan terhadap variabel Keputusan Pembelian.

b. Pengujian hipotesis 2

Variabel Persepsi Kualitas terhadap Keputusan Pembelian handphone Vivo.Berdasarkan tabel hasil Uji t untuk variabel, Persepsi Kualitas diperoleh nilai thitung $=3,694$ sedangkan $t$ tabel

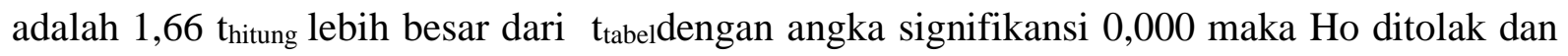
Ha diterima, Hal ini menunjukan bahwavariabel Persepsi Kualitas mempunyai pengaruh positif signifikan terhadap variabel Keputusan Pembelian.

c. Pengujian hipotesis 3

Variabel Loyalitas merek terhadap Keputusan Pembelian handphone Vivo. Berdasarkan tabel hasil Uji t untuk variabel Loyalitas merek, diperoleh nilai thitung $=3,348$ sedangkan ttabel adalah 1,66, thitung lebih besar dari tabeldengan angka signifikansi 0,001 maka Ho ditolak dan Ha diterima.Hal ini menunjukan bahwapada taraf signifikansi 0,05 Variabel Loyalitas merek mempunyai pengaruh positif signifikan terhadap variabel Keputusan Pembelian.

\section{PEMBAHASAN}

Pada Hipotesis pertama "Pengaruh Kesadaran merek tehadap Keputusan pembelian handphone Vivo pada Angkasa Cell di Kabupaten Blora".Hasil penelitian menunjukan bahwa variabel Kesadaran merekmempunyai pengaruh Positif dan signifikan terhadap Keputusan pembelian handphone Vivo pada Angkasa Cell di Kabupaten Blora. Hal ini ditunjukan dengan 
nilai koefesien regresi terbesar 0,301. Sedangkan untuk nilai $t$ hitung 3,958 $>t_{\text {tabel }}$ 1,66 dan sign 0,000, sehingga ada pengaruh Positif dan signifikan variabel Kesadaran merek terhadap Keputusan pembelian handphone Vivo pada angkasa cell di Kabupaten Blora.Hasil penelitian ini sejalan dengan penelitian yang dilakukan oleh Sumiati (2008)yang menyatakan bahwaada pengaruh kesadaran merek terhadap keputusan Pembelian Tablet Apple Ipad.

Pada hipotesis kedua "PengaruhPersepsi Kualitas terhadap Keputusan pembelian handphone Vivo pada Angkasa Cell di Kabupaten Blora”. Hasil penelitian ini menunjukan bahwa variabel Persepsi Kualitas mempunyai pengaruh yang signifikan terhadap Keputusan pembelian handphone Vivo pada angkasa cell di Kabupaten Blora. Hal ini menunjukan dengan nilai koefesien regresi sebesar 0,303. Sedangkan untuk nilai thitung 3.694> $t_{\text {tabel }} 1,66$ dan sign 0,000), sehingga ada pengaruh positif dan signifikan Persepsi Kualitas terhadap Keputusan pembelian handphone Vivo pada angkasa cell di Kabupaten Blora.Hasil penelitian ini tidak sejalan dengan penelitian yang dilakukan oleh Raja Bongsu Hutagalung dan Novi Aisha (2012), yang menunjukkan bahwafaktor pribadi, faktor psikologi berpengaruh secara positif dan tidak signifikan terhadap keputusan konsumen.

Hasil penelitian inisejalan Jesica Monica Reppi, Altje Tumbel, Rotinsulu Jopie Jorie (2015), yang menunjukkan Persepsi kualitas berpengaruh positif signifikan terhadap keputusan pembelian ponsel iphone pada pusat perbelanjaan ITC Manado.

Pada Hipotesis ketiga "Pengaruh Loyalitas merek terhadap Keputusan pembelian handphone Vivo pada Angkasa Cell di Kabupaten Blora”. Hasil penelitian menunjukan bahwa variabel Loyalitas merek mempunyai pengaruh yang signifikan terhadap Keputusan handphone Vivo pada angkasa cell di Kabupaten Blora. Hal ini menunjukan dengan nilai koefesien regresi sebesar 0,242. Sedangkan untuk nilai $t_{\text {hitung }}(3.438)>t_{\text {tabel }}(1,66)$ dan $\operatorname{sign}(0,001)<\operatorname{sign} a(0,05)$, sehingga hipotesis ketiga yang diajukan ada pengaruh positif dan signifikan Loyalitas merek terhadap Keputusan pembelian handphone Vivo pada Angkasa Cell di Kabupaten Blora, terbukti dapat diterima.Hasil penelitian ini juga sejalan dengan penelitian yang dilakukan oleh Jesica Monica Reppi, Altje Tumbel, Rotinsulu Jopie Jorie (2015), yang menunjukkan bahwa loyalitas berpengaruh positif signifikan terhadap keputusan pembelian ponsel iphone pada pusat perbelanjaan ITC Manado.

\section{KESIMPULAN}

1. Kesadaran merek mempunyai pengaruh Positif dan signifikan terhadap Keputusan pembelian handphone Vivo pada angkasa cell di Kabupaten Blora. 
2. Persepsi Kualitas mempunyai pengaruh yang signifikan terhadap Keputusan pembelian handphone Vivo pada angkasa cell di Kabupaten Blora

3. Loyalitas merek mempunyai pengaruh yang signifikan terhadap Keputusan handphone Vivo pada angkasa cell di Kabupaten Blora.

\section{DAFTAR PUSTAKA}

Aaker, David A. (1996). Manajemen Ekuitas Merek. (Alih bahasa: Aris Ananda).Jakarta: Spektrum Mitra Utama

Aaker David.A., 1991, Manajemen Equitas Merek, mamanfaatkan nilai dari suatu merek. Jakarta: Mitra Utama

Aaker, and Nagar. 2009. "Managing Assets and Skills : A Key to a Sustainable Competitive Advantage”. California Management Review Vol. 31 (Winter). pp. 91-106.

Assael, Henry. (1998) Cunsumer Behavior and Marketing Action, 6th Edition,Southwestern College Publishing: Cincinnati, Ohio

Arikunto, Suharsimi (ed). 1992. Prosedur Penelitian Suatu Pendekatan Praktek. Edisi Revisi. Jakarta: Rineka Cipta

Arikunto, Suharsimi. (2010). Prosedur Penelitian: Suatu Pendekatan Praktek.Jakarta: PT Rineka Cipta.

Bruhn, M., Schoenmueller, V., \& Schafer, D.B. (2012). Are Social Media Replacing Traditional Media in Terms of Brand Equity Creation? Management Research Review, Vol.35 No.9, pp.770-790.

Cronin, J Joseph dan Morris A Taylor. 1989. "Measuring Service Quality : A Reexamination and Extension”. Journal of Marketing Vol. 56 (July). pp. 55-68.

Chang, Hsin Hsin, Hsu Che-Hao dan Chung, Shu Hsia. (2008). The Antecedents and Consequences of Brand Equity in Service Markets. Asia Pasific Management Review, 13(3), 2008.

C. Mowen, John. Michael Minor. 2002. Perilaku Konsumen. Jakarta. Erlangga

Durianto, D, Sugiarto, \& Sitinjak, T. (2004). Strategi Menaklukkan Pasar MelaluiRiset Ekuitas dan Perilaku Merek. Jakarta: PT. Gramedia Pustaka Utama.

Durianto, Darmadi, Sugiarto dan Tony, Simanjuntak, "Strategi Menaklukan Pasar Melalui Riset Ekuitas dan Perilaku Merek”, PT. Gramedia Pustaka Utama, Jakarta, 2004.

Gujarati. 2003. Ekonometrika Dasar terj. Sumarno Zein. Jakarta: Erlangga. 
Ghozali, Imam (20011). Aplikasi Analisis Multivariate dengan Program IBM SPSS19. Semarang: Badan Penerbit Universitas Diponegoro

Ghozali, Imam. 2005. Aplikasi Analisis Multivariate Dengan Program SPSS. Semarang: Badan Penerbit Universitas Diponegoro.

Giddens. 2002. Customer Loyalty : Menumbuhkan dan Mempertahankan Kesetiaan Pelanggan. Ahli Bahasa : Dwi Kartini Jaya. Edisi Revisi dan Terbaru. Jakarta : Erlangga.

Gujarati, Damodar (1999) Essentials of Econometrics. Boston: Mc Graw-HillHuang, C. C, et. al. (2014). The Relationship Among Brand Equity, Custom

Hawkins, Del I (2007). Consumer Behavior: Building Marketing Strategy. NewYork: Irwin McGraw-Hill

Jogiyanto (2008). Pedoman Survey Kuesioner. Yogyakarta: BPFE

Kartajaya, Hermawan. (2004). Hermawan Kartajaya On Branding. Bandung:Mizan Media Utama

Kim, H.B. ve Kim, W.G. (2005) The Relationship Between Brand Equity and Firms' Performance in Luxury Hotels and Chain Restaurants, TourismManagement, 26:549-560

Kriyantono, Rachmat.2006. Teknik Praktis Riset Komunikasi. Jakarta: Kencana

Kotler Philip dan Amstrong, (2001). Prinsip-Prinsip Manajemen, Jilid 1 EdisiKedelapan, Alih Bahasa Oleh Damos Sihombing, MBA., Jakarta: Penerbit

Erlangga,

Kotler, Philip dan Kevin Lane Keller (2009). Manajemen Pemasaran (EdisiKedua Belas) Jakarta: Cetakan Ketiga, PT. Indeks

Malhotra. 2005. Riset Pemasaran. Jilid I. Edisi 4. Jakarta: Indeks Kelompok Gramedia

Paul, Peter. J dan Jerry C. Olson, 2000, Consumer Behaviour : Perilaku Konsumen dan Strategi Pemasaran, jilid 1 dan jilid 2, Jakarta : Erlangga.

Redaksi Majalah SWA (2007). Market share 2007. SWA No. 16/XXII/JULIAGUSTUS2007

Redaksi Majalah SWA (2008). Market share 2008. SWA NO.18/XXIV/AGUSTUSSEPTEMBER 2008Redaksi Majalah SWA (2009). Market share 2009. SWA NO.16/XXV/JULI -AGUSTUS 2009

Redaksi Majalah SWA (2010). Market share 2010. SWA NO.15/XXVI/15-18

JULI 2009

Redaksi Majalah SWA (2011). Market share 2011. SWA NO.15/XXVII/15-27JULI 2011

Rangkuti, Freddy. ((2009). Strategi Promosi yang Kreatif dan Analisis Kasus Integrated Marketing Communication. Jakarta : PT. GramediaPustakaUtama 
Simamora, Bilson. (2001). "Remarketing for Business Recovery, SebuahPendekatan Riset". Jakarta: Gramedia PU

Simamora, Bilson.(2004) Panduan Riset Perilaku Konsumen. Jakarta: GramediaPU

Sudarmadi (2014). Top 250 Indonesia Brand 2014. SWA edisi 16 (21 Juli-13Agustus 2014). Hlm. 33-38

Sutrisno, 2001, Manajemen Keuangan, Edisi Pertama, Cetakan Kedua, EKONISIA, Yogyakarta.

Sugiyono. (2007). Metode Penelitian Bisnis. Bandung : CV Alfabeta.

Sugiyono. 2008. Metode Penelitian Administrasi. Bandung: Alfabeta. 2009. Metode Penelitian Kuantitatif. Bandung: Alfabeta.

Schiffman, L. \& Kanuk, L, L. (2009). Perilaku Konsumen (edisi 7). Indeks. Jakarta.

Zeithaml, Valarie A., Mary Jo Bitner, dan Dwayne D. Gremler. (2006). ServiceMarketing Integrating Customer Focus Accross The Firm 4th Edition.New York:McGraw Hill. 